\title{
PENGARUH MANAJEMEN ASET DAN STRUKTUR MODAL TERHADAP PROFITABILITAS PADA PT ADHI KARYA (PERSERO), TBK YANG TERDAFTAR DI BURSA EFEK INDONESIA
}

\author{
Oleh: \\ Nelly Vika \\ S1 Akuntansi \\ Darwin Lie, Jubi, Ady Inrawan
}

Abstrak

Tujuan dari penelitian ini adalah untuk mengetahui gambaran manajemen aset, struktur modal, dan profitabilitas serta pengaruh manajemen aset dan struktur modal terhadap profitabilitas pada PT Adhi Karya (Persero), Tbk yang Terdaftar di Bursa Efek Indonesia secara simultan dan parsial. Metode analisis yang digunakan dalam penelitian ini adalah metode analisis deskriptif kualitatif dan analisis deskriptif kuantitatif. Objek penelitian ini adalah PT Adhi Karya (Persero), Tbk yang terdaftar di Bursa Efek Indonesia tahun 2008-2015. Metode yang digunakan untuk analisis data dalam penelitian ini adalah uji asumsi klasik, analisis regresi linier berganda, koefisien korelasi, koefisien determinasi, dan uji hipotesis (uji $\mathrm{F}$ dan uji t). Pengujian dilakukan dengan menggunakan bantuan program software SPSS versi 17.

Hasil analisa dari regresi linier berganda yaitu: $\hat{Y}=0,112+0,029 X_{1}-0,136 X_{2}$. Hal ini menunjukkan bahwa manajemen aset mempunyai pengaruh positif terhadap profitabilitas dan struktur modal mempunyai pengaruh negatif terhadap profitabilitas. Hasil kolerasi yaitu $r=0,894$ artinya terdapat hubungan yang sangat kuat antara manajemen aset dan struktur modal dengan profitabilitas. Dari koefisien determinasi profitabilitas dapat dijelaskan oleh manajemen aset dan struktur modal sebesar $80 \%$ dan sisanya $20 \%$ dijelaskan oleh variabel lain yang tidak dijelaskan dalam penelitian ini. Hipotesis penelitian $\mathrm{H}_{0}$ ditolak dengan tingkat signifikansi 0,000 lebih kecil dari $5 \%$ atau $0,000<0,05$, artinya manajemen aset dan struktur modal berpengaruh signifikan terhadap profitabilitas pada PT Adhi Karya (Persero), Tbk yang terdaftar di Bursa Efek Indonesia.

Kata Kunci: Manajemen Aset, Struktur Modal dan Profitabilitas

\section{Abstract}

The purpose of this research are to identify the description of asset management, equity structure and profitability and analyze the effect of asset management and equity structure towards profitability at PT Adhi Karya (Persero), Tbk which listed in Indonesia Stock Exchange either simultanly or partially. Methods of analysis used in this study are descriptive analysis of qualitative methods and quantitative descriptive analysis. The object of this research is PT Adhi Karya (Persero), Tbk which listed in the Indonesia Stock Exchange from 2008 until 2015. The method used for data analysis in this study is the classical assumption test, multiple linear regression analysis, the correlation coefficient of determination, and hypothesis test ( $F$ test and $t$ test). Testing is done with the help of Software SPSS version 17.

Result of analysis multiple linear regression that is: $\hat{Y}=0,112+0,029 X_{1}-0,136 X_{2}$. This shows that asset management have a positive effect to profitability and equity structure have a negative effect to profitability. The test results of correlation is $r=0,894$ means that there is very strong relationship between asset management and equity structure with profitability. From coefficient determination profitability can be explained by asset management and equity structure mounted to $80 \%$, and the rest $20 \%$ is explained by other variables that are not discussed in this study. The research hypothesis $H_{0}$ is rejected with the significance level 0,000 is smaller than $5 \%$ or $0,000<0,05$, means that asset management and equity structure simultanly have significant effect to the profitability at PT Adhi Karya (Persero), Tbk which listed in Indonesia Stock Exchange.

Keywords: Asset Management, Equity Structure and Profitability

\section{A. PENDAhUluan}

1. Latar Belakang Masalah

Suatu perusahaan didirikan dengan tujuan utama yaitu untuk mencari keuntungan agar perusahaan dapat berlangsung lama. Dalam mencapai tujuan tersebut tentunya perusahaan harus memperhatikan manajemen keuangannya. Salah satunya yaitu perusahaan harus mengetahui faktor-faktor yang mempengaruhi profitabilitas perusahaan agar perusahaan dapat mengambil berbagai keputusan untuk mendapatkan profitabilitas yang tinggi sehingga tujuan perusahaan dapat tercapai. 
Profitabilitas merupakan rasio yang digunakan untuk menilai kemampuan perusahaan untuk menghasilkan laba. Dalam perusahaan profitabilitas menunjukkan kemampuan perusahaan untuk menghasilkan laba dengan menggunakan aset yang ada di dalam perusahaan tersebut. Dengan mengetahui rasio ini, bisa diketahui seberapa besar kemampuan aset perusahaan untuk menghasilkan laba dengan kata lain tingkat pengembalian atas aktivanya.

Manajemen aset merupakan rasio yang mengukur kemampuan perusahaan dalam mengelola asetnya. Indikator yang digunakan untuk mengukur manajemen aset dalam penelitian ini total assets turnover ratio. Total assets turnover ratio adalah rasio yang mengukur efektivitas penggunaan seluruh aktiva dalam menghasilkan penjualan. Semakin besar rasio ini berarti semakin efektif pengelolaan seluruh aktiva yang dimiliki perusahaan dan sebaliknya.

Struktur modal adalah suatu struktur yang menggambarkan hutang jangka panjang dan modal dalam suatu perusahan. Indikator yang digunakan untuk mengukur struktur modal dalam penelitian ini adalah debt to assets ratio. Debt to assets ratio adalah rasio yang digunakan untuk mengukur seberapa besar hutang perusahaan dibanding dengan asetnya sehingga dapat diketahui kemampuan perusahaan untuk membiayai hutang tersebut dengan menggunakan asetnya.

\section{Rumusan Masalah}

a. Bagaimana gambaran manajemen aset, struktur modal, dan profitabilitas pada PT Adhi Karya (Persero), Tbk yang terdaftar di Bursa Efek Indonesia?

b. Bagaimana pengaruh manajemen aset dan struktur modal terhadap profitabilitas pada PT Adhi Karya (Persero), Tbk yang terdaftar di Bursa Efek Indonesia baik secara simultan maupun parsial?

\section{Tujuan Penelitian}

a. Untuk mengetahui gambaran manajemen aset, struktur modal, dan profitabilitas pada PT Adhi Karya (Persero), Tbk yang terdaftar di Bursa Efek Indonesia.

b. Untuk mengetahui pengaruh manajemen aset dan struktur modal terhadap profitabilitas pada PT Adhi Karya (Persero), Tbk yang terdaftar di Bursa Efek Indonesia baik secara simultan maupun parsial.

\section{Metode Penelitian}

Dalam penelitian ini, penulis mengambil objek penelitian pada PT Adhi Karya (Persero), Tbk yang terdaftar di Bursa Efek Indonesia dengan cara mengakses data dari situs www.idx.co.id.
Adapun desain penelitian yang digunakan dalam penulisan skripsi ini adalah penelitian kepustakaan (library research). Teknik pengumpulan data yang dilakukan penulis dalam penelitian ini adalah dokumentasi. Adapun jenis data yang digunakan dalam penelitian ini adalah jenis data kualitatif dan data kuantitatif. Hasil data yang diperoleh akan dianalisis secara deskriptif baik bersifat kualitatif dan kuantitatif.

\section{B. LANDASAN TEORI}

\section{Laporan Keuangan}

Menurut Baridwan (2004:17), laporan keuangan merupakan ringkasan dari suatu proses pencatatan dari transaksi-transaksi keuangan yang terjadi selama tahun buku yang bersangkutan.

Adapun jenis-jenis laporan keuangan menurut PSAK (Pernyataan Standar Akuntansi Keuangan) 1 dalam Martani, dkk (2012:10) terdiri dari lima jenis, yaitu:

a. Laporan Posisi Keuangan adalah daftar yang sistematis dari aset, hutang, dan modal pada tanggal tertentu, yang biasanya dibuat pada akhir tahun.

b. Laporan Laba Rugi Komprehensif adalah ikhtisar mengenai pendapatan dan beban suatu entitas untuk periode tertentu, sehingga dapat diketahui laba yang diperoleh dan rugi yang dialami.

c. Laporan Arus Kas, dengan adanya laporan ini, pemakai laporan keuangan dapat mengevaluasi perubahan aset neto entitas, struktur keuangan (termasuk likuiditas dan solvabilitas) dan kemampuan entitas untuk menghasilkan kas di masa mendatang.

d. Laporan Perubahan Ekuitas adalah laporan yang menunjukkan perubahan ekuitas untuk periode tertentu, bisa satu bulan atau satu tahun. Melalui laporan perubahan ekuitas, pembaca laporan dapat mengetahui sebabsebab perubahan ekuitas selama periode tertentu.

e. Catatan atas Laporan Keuangan merupakan laporan yang berisi informasi tambahan atas apa yang disajikan dalam empat laporan di atas. Laporan ini memberikan penjelasan atau rincian pos-pos yang disajikan dalam laporan keuangan dan informasi mengenai pos-pos yang tidak memenuhi kriteria pengakuan dalam laporan keuangan.

\section{Analisis Rasio Keuangan}

Menurut Horne dan John (2012:163) rasio keuangan merupakan indeks yang menghubungkan dua buah data keuangan dengan membagi satu angka dengan angka lainnya.

Ada beberapa jenis rasio keuangan menurut Brigham dan Joel (2010:134), yaitu: 
a. Liquidity Ratio, yaitu rasio yang menunjukkan hubungan antara kas dan aset lancar perusahaan lainnya dengan kewajiban lancarnya.

b. Asset Management Ratio, yaitu rasio yang mengukur seberapa efektif sebuah perusahaan mengatur asetnya.

c. Financial Leverage, yaitu rasio yang menggambarkan penggunaan pendanaan hutang.

d. Profitability Ratio, yaitu sekelompok rasio yang menunjukkan kombinasi dari pengaruh likuiditas, manajemen aset, dan hutang pada hasil operasi.

e. Market Value Ratio, yaitu sekumpulan rasio yang menghubungkan harga saham perusahaan dengan laba, arus kas, dan nilai buku per sahamnya.

\section{Manajemen Aset}

Menurut Astuti (2004:32), rasio manajemen aset mengukur efektivitas perusahaan dalam mengelola aktivanya, yaitu mengukur kemampuan seluruh aktivanya dalam menghasilkan penjualan. Rasio aktivitas ini menunjukkan seberapa cepat aktiva lancar dapat dikonversikan ke dalam kas.

Adapun rasio manajemen aset yang diuraikan oleh Brigham dan Joel (2010:136), yaitu:

a. Rasio perputaran persediaan (Inventory turnover ratio) merupakan rasio yang mengukur perputaran persediaan dalam menghasilkan penjualan, dan semakin tinggi rasio berarti semakin efektif dan efisien pengelolaan persediaan yang dilakukan oleh manajemen perusahaan untuk menghasilkan penjualan, dan sebaliknya (Sudana, 2011:22). Adapun rumus untuk menghitung Inventory turnover ratio, yaitu:

Inventory turnover ratio $=\frac{\text { Penjualan }}{\text { Persediaan }}$

b. Jumlah hari penjualan belum tertagih (Days sales outstanding-DSO) mengukur rata-rata waktu yang diperkukan untuk menerima kas dari penjualan. Semakin besar rasio ini menunjukkan semakin tidak efektif dan tidak efisiennya pengelolaan piutang yang dilakukan oleh manajemen perusahaan (Sudana, 2011:22). Rumus yang digunakan untuk mengukur $D S O$ :

Days sales outstanding $=\frac{360}{\text { Perputaran Piutang }}$

c. Rasio perputaran aset tetap (Fixed asset turnover ratio) mengukur efektivitas penggunaan aktiva tetap dalam menghasilkan penjualan bagi perusahaan. Semakin tinggi rasio ini semakin efektif pengelolaan aktiva tetap yang dilakukan oleh manajemen perusahaan (Sudana, 2011:22). Rumus untuk mengukur Fixed asset turnover ratio, yaitu:
Fixed asset turnover ratio $=\frac{\text { Penjualan }}{\text { Total Aset Tetap }}$

d. Rasio perputaran total aset (Total assets turnover ratio) yaitu rasio yang mengukur efektivitas penggunaan seluruh aktiva dalam menghasilkan penjualan. Semakin besar rasio ini berarti semakin efektif pengelolaan seluruh aktiva yang dimiliki perusahaan (Sudana, 2011:22). Rasio ini dapat dirumuskan sebagai berikut

Total assets turnover ratio $=\frac{\text { Penjualan }}{\text { Total Aset }}$

Dalam penulisan ini, penulis membatasi penelitian dengan hanya menggunakan total assets turnover ratio sebagai indikator untuk mengukur manajemen aset. Total assets turnover ratio yaitu rasio yang mengukur efisiensi dan efektivitas perusahaan dalam mengelola total asetnya untuk menghasilkan penjualan.

\section{Struktur Modal}

Menurut Astuti (2004:138), struktur modal adalah bauran atau perpaduan dari hutang jangka panjang, saham preferen dan saham biasa. Struktur modal yang ditargetkan adalah perpaduan antara hutang, saham preferen, saham biasa yang dikehendaki perusahaan dalam struktur modalnya.

Struktur modal yang sering disebut juga dengan leverage, menurut Kasmir (2010:112), secara umum rasio-rasio leverage adalah sebagai berikut:

a. Debt to Assets Ratio (DAR) atau Debt Ratio (DR) adalah rasio utang yang digunakan untuk mengukur seberapa besar aktiva perusahaan dibiayai oleh utang atau seberapa besar utang perusahaan berpengaruh terhadap pengelolaan aktiva. Caranya adalah dengan membandingkan antara total utang dengan total aktiva.

Debt to Assets Ratio $=\frac{\text { Total Debt }}{\text { Total Assets }}$

b. Debt to Equity Ratio (DER), merupakan rasio yang digunakan untuk menilai utang dengan ekuitas. Untuk mencari rasio ini dengan cara membandingkan antara seluruh utang, termasuk utang lancar dengan seluruh ekuitas. Rasio ini berguna untuk mengetahui jumlah dana yang disediakan peminjam (kreditur) dengan pemilik perusahaan. Dengan kata lain, rasio ini berfungsi untuk mengetahui setiap rupiah modal sendiri yang dijadikan untuk jaminan utang.

Debt to Equity Ratio $=\frac{\text { Total Debt }}{\text { Equity }}$

c. Long Term Debt to Equity Ratio adalah rasio antara utang jangka panjang dengan modal sendiri. Tujuannya adalah untuk mengukur berapa bagian dari setiap rupiah modal sendiri yang dijadikan jaminan utang jangka panjang dengan cara membandingkan 
antara utang jangka panjang dengan modal yang disediakan oleh perusahaan.

Long Term Debt to Equity Ratio $=\frac{\text { Long Term Debt }}{\text { Equity }}$

d. Times Interest Earned, merupakan rasio untuk mencari jumlah kali perolehan bunga (Weston dalam Kasmir, 2010). Rasio ini diartikan juga kemampuan perusahaan untuk membayar biaya bunga, sama seperti coverage ratio (Horne dalam Kasmir, 2010). Times Interest Earned $=\frac{\mathrm{EBIT}}{\text { Interest }}$ atau $\frac{\mathrm{EBT}+\text { Interest }}{\text { Interest }}$

e. Fixed Charge Coverage adalah rasio yang menyerupai rasio Times Interest Earned. Hanya saja bedanya dalam rasio ini dilakukan, apabila perusahaan memperoleh utang jangka panjang atau menyewa aktiva berdasarkan kontrak sewa (lease control). Biaya tetap merupakan biaya bunga ditambah kewajiban sewa tahunan atau jangka panjang.

Fixed Charge Coverage $=\frac{\text { EBT }+ \text { Biaya Bunga }+ \text { Kewajiban Sewa }}{\text { Biaya Bunga }+ \text { Kewajiban Sewa }}$

Dalam penulisan ini, penulis membatasi penelitian dengan hanya menggunakan Debt to Assets Ratio (DAR) untuk mengukur indikator struktur modal. Alasan digunakan Debt to Assets Ratio (DAR) adalah untuk mengetahui seberapa besar aktiva perusahaan dibiayai oleh utang.

\section{Profitabilitas}

Menurut Fraser dan Aileen (2008:222), rasio profitabiltas merupakan rasio yang mengukur kinerja keseluruhan sebuah perusahaan dan efisiensinya dalam mengelola aktiva, kewajiban dan ekuitas.

Menurut Sudana (2011:22), terdapat beberapa cara untuk mengukur besar kecilnya profitabilitas, yaitu:

a. Return on assets (ROA) menunjukkan kemampuan perusahaan dengan menggunakan seluruh aktiva yang dimiliki untuk menghasilkan laba setelah pajak. Rasio ini penting bagi pihak manajemen untuk mengevaluasi efektivitas dan efisiensi manajemen perusahaan dalam mengelola seluruh aset perusahaan. Semakin besar return on assets berarti semakin efisien penggunaan aset perusahaan atau dengan kata lain dengan jumlah aset yang sama bisa dihasilkan laba yang lebih besar, dan sebaliknya. Rumus untuk mencari return on assets, yaitu :

Return on Assets $=\frac{\text { Laba Setelah Pajak }}{\text { Total Aset }}$

b. Return on equity (ROE) menunjukkan kemampuan perusahaan untuk menghasilkan laba setelah pajak dengan menggunakan modal sendiri yang dimiliki perusahaan. Rasio ini penting bagi pihak pemegang saham untuk mengetahui efektivitas dan efisiensi pengelolaan modal sendiri yang dilakukan oleh pihak manajemen perusahaan. Semakin tinggi rasio ini berarti semakin efisien penggunaan modal sendiri yang dilakukan oleh pihak manajemen perusahaan. Rumus untuk mencari Return On Equity, yaitu:

Return on Equity $=\frac{\text { Laba Setelah Pajak }}{\text { Total Modal }}$

c. Profit margin ratio mengukur kemampuan perusahaan untuk menghasilkan laba dengan menggunakan penjualan yang dicapai perusahaan. Semakin tinggi rasio menunjukkan bahwa perusahaan semakin efisien dalam menjalankan operasinya. Profit margin dibedakan menjadi:

1) Net profit margin mengukur kemampuan perusahaan untuk menghasilkan laba bersih dari penjualan yang dilakukan perusahaan. Rasio ini mencerminkan efisiensi seluruh bagian, yaitu produksi, personalia, pemasaran, dan keuangan yang ada dalam perusahaan. Rumus untuk mencari net profit margin, yaitu:

Net Profit Margin $=\frac{\text { Laba Setelah Pajak }}{\text { Penjualan }}$

2) Operating profit margin mengukur kemampuan untuk menghasilkan laba sebelum bunga dan pajak dengan penjualan yang dicapai perusahaan. Rasio ini menunjukkan efisiensi bagian produksi, personalia, serta pemasaran dalam menghasilkan laba. Rumus untuk mencari Operating Profit Margin yaitu: Operating Profit Margin $=\frac{\text { Laba Sebelum Bunga dan Pajak }}{\text { Penjualan }}$

3) Gross profit margin mengukur kemampuan perusahaan untuk menghasilkan laba kotor dengan penjualan yang dilakukan perusahaan. Rasio ini menggambarkan efisiensi yang dicapai oleh bagian produksi. Rumus untuk mencari Gross Profit Margin yaitu:

Gross Profit Margin $=\frac{\text { Laba Kotor }}{\text { Penjualan }}$

d. Basic earning power mengukur kemampuan perusahaan untuk menghasilkan laba sebelum bunga dan pajak dengan menggunakan total aktiva yang dimiliki perusahaan. Dengan kata lain rasio ini mencerminkan efektivitas dan efisiensi pengelolaan seluruh investasi yang telah dilakukan oleh perusahaan. Semakin tinggi rasio ini berarti semakin efektif dan efisien pengelolaan seluruh aktiva yang dimiliki perusahaan untuk menghasilkan laba sebelum bunga dan pajak. Rasio ini dihitung dengan rumus:

Basic Earning Power $=\frac{\text { Laba Sebelum Bunga dan Pajak }}{\text { Tol }}$ 
Dalam penelitian ini, parameter profitabilitas yang digunakan adalah Return on Assets $(R O A)$ yaitu persentase dari laba bersih yang diperoleh dari total aset yang dimiliki oleh perusahaan

\section{Pengaruh Manajemen Aset dan Struktur Modal Terhadap Profitabilitas}

Perusahaan mengelola aset melalui kebijakan operasional perusahaan agar tidak terjadi penumpukan aset untuk memproduktifkan aset yang ada sehingga tidak ada aset perusahaan yang menganggur atau tidak memberikan pengembalian. Manajemen aset adalah kemampuan perusahaan dalam menghasilkan penjualan pada tingkat aset tertentu. Jadi, semakin baik perusahaan mengelola aset-asetnya, semakin tinggi angka penjualan perusahaan diikuti dengan meningkatnya laba kotor (laba sebelum bunga, pajak, depresiasi, dan amortisasi). Menurut Silaban dan Rusliaman (2011:104) jika perusahaan memiliki aktiva yang terlalu banyak, maka biaya modal akan menjadi terlalu tinggi sehingga laba akan menurun. Jika perusahaan memiliki aktiva yang terlalu kecil, maka penjualan yang menguntungkan tidak akan diperoleh (hilang).

Kebijakan struktur modal merupakan trade off antara risk dan return. Utang meningkat, maka risk meningkat sehingga return juga meningkat. Apabila risk meningkat, maka harga saham turun, tetapi jika return meningkat maka harga saham naik. Karena itu, struktur modal yang optimal harus berada pada keseimbangan antara risiko dan pengembalian yang memaksimumkan harga saham Sesungguhnya, tidak seorang pun mengetahui bagaimana menentukan secara persis struktur modal yang optimal untuk suatu perusahaan. Berdasarkan teori trade off, keputusan perusahaan menggunakan utang didasarkan kepada keseimbangan antara penghematan pajak dan biaya kesulitan keuangan.

Menurut Sudana (2011:153) berdasarkan signaling theory (teori sinyal), perusahaan yang mampu menghasilkan laba cenderung meningkatkan jumlah utangnya, karena tambahan pembayaran bunga akan diimbangi dengan laba sebelum pajak. Semakin sukses suatu perusahaan, kemungkinan akan menggunakan lebih banyak utang. Jadi dapat disimpulkan semakin tinggi rasio hutang terhadap total aset, semakin besar resiko keuangannya dimana resiko keuangan mempunyai hubungan positif dengan tingkat pengembalian sehingga jika semakin tinggi rasio hutang terhadap total aset, maka semakin besar tingkat pengembalian dan sebaliknya

\section{PEMBAHASAN}

\section{Analisa}

a. Uji Asumsi Klasik

Uji normalitas dengan pengujian One Sample Kolmogorov-Smirnov diperoleh nilai Asymp Sig. (2-tailed) sebesar 0,711 yang berarti nilai tersebut di atas nilai signifikan 0,05 atau 0,711 > 0,05. Dengan demikian dapat dikatakan bahwa variabel residual berdistribusi normal. Untuk uji multikolineritas, menunjukkan bahwa variabel manajemen aset dan struktur modal semuanya tidak terjadi multikolineritas karena nilai tolerance berada di atas 0,10 dan nilai VIF berada di bawah 10 .

Dari grafik scatterplot terlihat bahwa plot menyebar secara acak di atas maupun di bawah angka nol pada sumbu Regression Studentized Residual. Oleh karena itu, maka berdasarkan uji heteroskedastisitas menggunakan metode analisis grafik, pada model regresi yang terbentuk dinyatakan tidak terjadi gejala heteroskedastisitas. Nilai DurbinWatson dalam penelitian ini adalah sebesar 1,533. Berdasarkan tabel Durbin-Watson diketahui bahwa nilai dL untuk data sebanyak 32 dan $\mathrm{k}=2$ adalah sebesar 1,309 dan nilai dU sebesar 1,574 sehingga dari hasil pengujian, Durbin-Watson terletak di antara nilai dL dan dU atau 1,309 < 1,533 < 1,574, maka hasil uji autokorelasi tersebut adalah tanpa kesimpulan (no desicion).

\section{b. Deskriptif Kualitatif}

Analisis deskriptif dalam penelitian ini bertujuan untuk mendapatkan gambaran atau deskripsi mengenai manajemen aset, struktur modal, dan profitabilitas pada PT Adhi Karya (Persero), Tbk yang terdaftar di Bursa Efek Indonesia periode 2008-2015.

\section{1) Manajemen Aset pada PT Adhi Karya (Persero), Tbk yang Terdaftar di Bursa Efek Indonesia Tahun 2008-2015}

Dari hasil penelitian, diketahui bahwa nilai minimum dari manajemen aset yang diukur dengan total assets turnover ratio pada PT Adhi Karya (Persero), Tbk yang terdaftar di Bursa Efek Indonesia periode 2008-2015 yaitu sebesar 0,0999, yang artinya total aset sebesar $\mathrm{Rp} 1$ dapat menghasilkan penjualan sebesar $\mathrm{Rp}$ 0,0999 . Total assets turnover ratio minimum terjadi pada tahun 2012 yaitu pada triwulan pertama.

Total assets turnover ratio maksimum perusahaan adalah sebesar 1,3704, yang artinya total aset sebesar $R p 1$ dapat menghasilkan penjualan sebesar $\mathrm{Rp} 1,3704$. Total assets turnover ratio maksimum terjadi pada periode 2009 triwulan keempat. Pada periode ini, terjadi peningkatan yang cukup besar pada penjualan sedangkan peningkatan total aset hanya sedikit saja atau dengan kata lain peningkatan penjualan tidak diimbangi 
dengan peningkatan total aset. Oleh karena itu total assets turnover ratio meningkat hingga mencapai nilai maksimum dalam periode 20082015.

Nilai rata-rata total assets turnover ratio perusahaan pada periode 2008-2015 adalah sebesar 0,5481. Periode yang berada di bawah rata-rata yaitu tahun 2008 triwulan pertama dan triwulan kedua, tahun 2009 triwulan pertama, tahun 2010 dan 2011 masing-masing pada triwulan pertama dan kedua, kemudian tahun 2012 triwulan pertama sampai triwulan ketiga, tahun 2013 triwulan pertama dan kedua, serta tahun 2014 dan 2015 masing-masing pada triwulan pertama sampai triwulan ketiga. Sedangkan yang berada di atas rata-rata adalah tahun 2008 triwulan ketiga dan triwulan keempat, tahun 2009 triwulan kedua sampai triwulan keempat, tahun 2010 dan 2011 masing-masing triwulan ketiga dan triwulan keempat, kemudian tahun 2012 triwulan keempat, tahun 2013 triwulan ketiga dan triwulan keempat serta tahun 2014 dan 2015 masing-masing pada triwulan keempat.

\section{2) Struktur Modal pada PT Adhi Karya (Persero), Tbk yang Terdaftar di Bursa Efek Indonesia tahun 2008-2015}

Dari hasil penelitian, diketahui bahwa nilai minimum dari struktur modal yang diukur dengan debt to assets ratio pada PT Adhi Karya (Persero), Tbk yang terdaftar di Bursa Efek Indonesia periode 2008-2015 yaitu sebesar 0,6920 , yang artinya setiap $R p 1$ aset membiayai 0,6920 hutang perusahaan. Debt to assets ratio minimum terjadi pada tahun 2015. Debt to assets ratio maksimum perusahaan adalah sebesar 0,8830 , yang artinya setiap $R p$ 1 aset membiayai 0,6920 hutang perusahaan. Debt to assets ratio minimum terjadi pada tahun 2015 yaitu pada triwulan keempat. Hal ini disebabkan peningkatan total hutang tidak sebanding dengan peningkatan total aset sehingga jumlah total aset jauh lebih tinggi, sedangkan kenaikan total hutang stabil dari tahun-tahun sebelumnya.

Debt to assets ratio maksimum perusahaan adalah sebesar 0,8852, yang artinya kemampuan perusahaan untuk memenuhi hutangnya adalah sebesar $\mathrm{Rp}$ 0,8852 dengan menggunakan $\mathrm{Rp} 1$ aset perusahaan. Debt to assets ratio maksimum terjadi pada periode 2009 triwulan ketiga. Pada periode ini, terjadi peningkatan total hutang yang tidak diimbangi dengan peningkatan total aset sehingga kemampuan perusahaan untuk memenuhi hutangnya semakin menurun.

Nilai rata-rata debt to assets ratio perusahaan pada periode 2008-2015 adalah sebesar 0,8495 . Periode yang berada di bawah rata-rata yaitu tahun 2010 triwulan ketiga sampai tahun 2012 triwulan kedua, kemudian pada tahun 2014 triwulan pertama sampai tahun 2015 triwulan pertama, selanjutnya pada tahun 2015 triwulan keempat. Sedangkan yang berada di atas rata-rata adalah tahun 2008 triwulan pertama sampai 2010 triwulan kedua, kemudian tahun 2012 triwulan ketiga sampai 2013 triwulan keempat serta tahun 2015 triwulan kedua dan ketiga.

\section{3) Profitabilitas pada PT Adhi Karya} (Persero), Tbk yang Terdaftar di Bursa Efek Indonesia tahun 2009-2015

Dari hasil penelitian, diketahui bahwa nilai minimum dari profitabilitas yang diukur dengan return on assets pada PT Adhi Karya (Persero), Tbk yang terdaftar di Bursa Efek Indonesia periode 2008-2015 yaitu sebesar 0,0001 , yang artinya setiap Rp 1 aset dapat menghasilkan laba bersih setelah pajak sebesar Rp 0,001. Return on assets minimum terjadi pada tahun 2009 triwulan pertama dan tahun 2010 triwulan pertama. Hal ini disebabkan adanya penurunan yang drastis pada jumlah laba bersih setelah pajak dimana total aset tetap stabil dari periode ke periode atau dengan kata lain tidak terjadi perubahan yang tinggi, Sehingga profitabilitas perusahaan menjadi menurun sampai mencapai nilai paling minimum yaitu 0,001 .

Return on assets maksimum perusahaan adalah sebesar 0,0420, yang artinya setiap Rp 1 aset dapat menghasilkan laba bersih setelah pajak sebesar Rp 0, 0420. Return on assets maksimum terjadi pada periode 2013 triwulan keempat. Pada periode ini, terjadi peningkatan laba bersih setelah pajak yang drastis sedangkan total aset hanya terjadi sedikit peningkatan atau dengan kata lain kenaikan laba bersih setelah pajak tidak diimbangi dengan kenaikan total aset.

Nilai rata-rata return on assets perusahaan pada periode 2008-2015 adalah sebesar 0,0121 . Periode yang berada di bawah rata-rata yaitu tahun 2008 triwulan pertama sampai triwulan ketiga dan tahun 2009 triwulan pertama sampai triwulan ketiga, kemudian tahun 2010 triwulan pertama dan kedua, tahun 2011 triwulan pertama sampai triwulan ketiga, selanjutnya tahun 2012 dan 2013 masingmasing triwulan pertama dan kedua serta tahun 2014 dan 2015 masing-masing dari triwulan pertama sampai triwulan ketiga. Sedangkan yang berada di atas rata-rata adalah tahun 2008 triwulan keempat, tahun 2009 triwulan keempat, tahun 2010 triwulan ketiga dan keempat, kemudian tahun 2011 triwulan keempat, tahun 2012 triwulan ketiga dan keempat, tahun 2013 triwulan ketiga dan keempat, selanjutnya tahun 2014 triwulan keempat dan tahun 2015 triwulan keempat.

\section{c. Deskriptif Kuantitatif}




\section{1) Analisis Regresi Linier Berganda}

Berdasarkan hasil analisis dengan program SPSS, maka model regresi linear berganda yaitu sebagai berikut : $\hat{Y}=0,112+0,029 X_{1}-0,136 X_{2}$

Berdasarkan hasil persamaan regresi di atas maka dapat disimpulkan bahwa manajemen aset berpengaruh positif sedangkan struktur modal berpengaruh negatif terhadap profitabilitas pada PT Adhi Karya (Persero), Tbk yang terdaftar di Bursa Efek Indonesia periode 2008-2015.

\section{2) Analisa Korelasi dan Determinasi}

Berdasarkan hasil pengolahan data SPSS diperoleh nilai koefisien korelasi adalah sebesar 0,894, yang artinya terdapat korelasi atau hubungan yang sangat kuat antara manajemen aset dan struktur modal dengan profitabilitas.

Untuk nilai koefisien determinasi adalah sebesar 0,800. Angka ini mempunyai arti bahwa $80 \%$ variasi dari profitabilitas yang diproksikan dengan return on assets dijelaskan oleh variasi dari kedua variabel independen yaitu manajemen aset yang diproksikan dengan total assets turnover ratio dan struktur modal yang diproksikan dengan debt to assets ratio, sedangkan sisanya yaitu $20 \%$ dijelaskan oleh variabel lain seperti profit margin dan operating assets turnover.

\section{3) Uji Hipotesis}

\section{a) Uji Simultan (Uji F)}

Uji statistik $F$ pada dasarnya menunjukkan apakah semua variabel independen yang dimasukkan dalam model mempunyai pengaruh secara simultan terhadap variabel dependen.

Uji ini dilakukan dengan membandingkan signifikansi $F_{\text {hitung }}$ dengan $F_{\text {tabel }}$ dengan ketentuan sebagai berikut:

(1) Jika $F_{\text {hitung }}>F_{\text {tabel }}$ dan nilai probabilitas < 0,05 maka $H_{0}$ ditolak, yang berarti manajemen aset dan struktur modal secara silmultan berpengaruh signifikan terhadap profitabilitas.

(2) Jika $F_{\text {hitung }}<F_{\text {tabel }}$ dan nilai probabilitas $>$ 0,05 maka $\mathrm{H}_{0}$ diterima, yang berarti bahwa manajemen aset dan struktur modal secara silmultan berpengaruh tidak signifikan terhadap profitabilitas.

Dari hasil pengolahan data, dapat dilihat bahwa dengan tingkat kepercayaan $95 \%$, n-k$1=32-2-1=29$, diperoleh angka $F_{\text {tabel }}$ sebesar 3,328 dan besar $F_{\text {hitung }}$ adalah 57,938. Karena $\mathrm{F}_{\text {hitung }}>\mathrm{F}_{\text {tabel }}$ atau $57,938>3,328$ maka $\mathrm{H}_{0}$ ditolak dan untuk tingkat signifikansi adalah $0,000<0,05$, maka keputusan yang diambil adalah manajemen aset dan struktur modal berpengaruh signifikan terhadap profitabilitas pada PT Adhi Karya (Persero), Tbk yang terdaftar di Bursa Efek Indonesia.

\section{b) Uji Parsial (Uji t)}

Uji t digunakan untuk menguji pengaruh variabel bebas terhadap variabel terikat secara parsial atau individual. Adapun hipotesis yang diuji adalah sebagai berikut:

(1) $\mathrm{H}_{0}$ ditolak jika thitung $>t_{\text {tabel }}$, artinya manajemen aset dan struktur modal secara parsial berpengaruh signifikan terhadap profitabilitas.

(2) $\mathrm{H}_{0}$ diterima jika $t_{\text {hitung }}<t_{\text {tabel }}$, artinya manajemen aset dan struktur modal secara parsial berpengaruh tidak signifikan terhadap profitabilitas.

Hipotesis digunakan untuk menguji signifikansi koefisien persamaan regresi dirumuskan sebagai berikut :

(1) Jika $t_{\text {hitung }}>t_{\text {tabel }}$ atau probabilitas signifikan $<\alpha(5 \%)$, maka $\mathrm{H}_{0}$ ditolak.

(2) Jika $t_{\text {hitung }}<t_{\text {tabel }}$ atau probabilitas signifikan $>\alpha(5 \%)$, maka $\mathrm{H}_{0}$ diterima.

Dari hasil uji t diperoleh kesimpulan sebagai berikut:

(1) Untuk variabel manajemen aset dengan tingkat kepercayaan 95\%, n-k-1=32-2-1=29 dan $\alpha=5 \%$, dari tabel t diperoleh angka $t_{\text {tabel }}$ sebesar 2,045 dan besar $t_{\text {hitung }}$ adalah 10,170 . Karena $t_{\text {hitung }}>t_{\text {tabel }}$ atau $10,170>$ 2,045 maka $\mathrm{H}_{0}$ ditolak, artinya manajemen aset berpengaruh signifikan terhadap profitabilitas pada PT Adhi Karya (Persero), Tbk yang terdaftar di Bursa Efek Indonesia secara parsial.

(2) Untuk variabel struktur modal dengan tingkat kepercayaan 95\%, n-k-1=32-2-1=29 dan $\alpha=5 \%$, dari tabel t diperoleh angka $t_{\text {tabel }}$ sebesar 2,045 dan besar $t_{\text {hitung }}$ adalah 4,411. Karena $t_{\text {hitung }}>t_{\text {tabel }}$ atau $4,411>$ 2,045 maka $\mathrm{H}_{0}$ ditolak, artinya struktur modal berpengaruh signifikan terhadap profitabilitas pada PT Adhi Karya (Persero), Tbk yang terdaftar di Bursa Efek Indonesia secara parsial.

\section{Evaluasi}

a. Manajemen Aset pada PT Adhi Karya (Persero), Tbk yang Terdaftar di Bursa Efek Indonesia

Hasil analisis menunjukkan kondisi manajemen aset PT Adhi Karya (Persero), Tbk tahun 2008-2015 mengalami fluktuasi. Nilai minimum manajemen aset yang diproksikan dengan total assets turnover ratio adalah sebesar 0,5602, yang terjadi pada tahun 2015 dengan jumlah penjualan sebesar $R p$ 9.389.570.098.578 dan total aset sebesar $R p$ 16.761.063.514.879.

Dalam hal ini sebaiknya perusahaan tidak menambah terlalu banyak aset apabila aset tersebut tidak dapat mendukung peningkatan 
penjualan karena aset yang terlalu besar justru akan menimbulkan biaya yang semakin besar juga, seperti biaya penyusutan maupun biaya pemeliharaan. Pada laporan posisi keuangan tahun 2015 dapat dilihat bahwa peningkatan kas dibandingkan tahun lalu adalah sebesar $\mathrm{Rp}$ 3.505.936.179.991 yaitu dari $R p$ 811.411.723.393 menjadi $\mathrm{Rp}$ 43.17.347.903.384. Saldo kas yang meningkat secara drastis tersebut sebaiknya diinvestasikan agar dapat menghasilkan keuntungan yang lebih besar kepada perusahaan atas investasi tersebut.

\section{b. Struktur Modal pada PT Adhi Karya (Persero), Tbk yang Terdaftar di Bursa Efek Indonesia}

Hasil analisis menunjukkan kondisi struktur modal yang diukur dengan debt to assets ratio pada PT Adhi Karya (Persero), Tbk periode 2008 sampai 2015 mengalami fluktuasi. Debt to assets ratio maksimum perusahaan adalah sebesar 0,8830 yang terjadi pada tahun 2008 dengan total hutang sebesar $\mathrm{Rp}$ 4.525.468.985.337 dan total aset sebesar $R p$ 5.125.368.541.520. Dalam hal ini sebaiknya perusahaan tidak menambah terlalu banyak hutang karena hutang yang terlalu tinggi akan menyebabkan biaya bunga menjadi tinggi yang akan berdampak pada penurunan laba perusahaan. Hal ini sesuai dengan hasil penelitian yaitu debt to assets ratio mempunyai hubungan yang negatif terhadap return on assets perusahaan.

\section{c. Profitabilitas pada PT Adhi Karya (Persero), Tbk yang Terdaftar di Bursa Efek Indonesia}

Dari hasil penelitian, menunjukkan kondisi profitabilitas PT Adhi Karya (Persero), Tbk periode 2008-2015 yang diukur dengan menggunakan return on assets (ROA) mengalami fluktuasi. Dimana return on assets minimum perusahaan adalah sebesar 0,0162 yang terjadi pada tahun 2008 dengan laba bersih setelah pajak sebesar $\mathrm{Rp}$ 82.994.360.378 dan total aset sebesar $\mathrm{Rp}$ 5.125.368.541.520. Dalam hal ini sebaiknya perusahaan memaksimalkan penggunaan total aset yang dimiliki perusahaan agar dapat menghasilkan penjualan yang lebih tingg sehingga perputaran aset untuk menghasilkan penjualan semakin besar juga serta akan turut meningkatkan laba perusahaan. Juga sebaiknya tidak menambah terlalu banyak aset karena peningkatan aset yang terlalu besar akan meningkatkan biaya juga, seperti biaya penyusutan dan biaya pemeliharaan.

\section{d. Pengaruh Pengaruh Manajemen Aset dan Struktur Modal Terhadap Profitabilitas}

pada PT Adhi Karya (Persero), Tbk yang Terdaftar di Bursa Efek Indonesia

Berdasarkan hasil analisis regresi linier berganda maka model persamaan regresi adalah $\hat{Y}=0,112+0,029 X_{1}-0,136 X_{2}$ yang artinya manajemen aset berpengaruh positif sedangkan struktur modal berpengaruh negatif terhadap profitabilitas pada PT Adhi Karya (Persero), Tbk yang terdaftar di Bursa Efek Indonesia periode 2008-2015.

Berdasarkan pengujian koefisien korelasi dan determinasi diketahui bahwa nilai $r$ adalah 0,894 yang berarti bahwa terdapat korelasi atau hubungan yang sangat kuat antara variabel manajemen aset dan struktur modal dengan profitabilitas. Sementara koefisien determinasi (R Square) adalah 0,800, hal ini berarti $80 \%$ variasi dari profitabilitas dijelaskan oleh variasi dari kedua variabel independen (manajemen aset dan struktur modal), sedangkan sisanya dijelaskan oleh variabel lain seperti profit margin dan operating assets turnover.

Berdasarkan uji simultan (uji F) diperoleh nilai $F_{\text {hitung }}$ sebesar 57,938 sedangkan $F_{\text {tabel }}$ dengan $(0,05 ; 2$ VS (32-2-1)) sebesar 3,328, atau dengan signifikansi $0,000<0,05$ maka $\mathrm{H}_{0}$ ditolak, yang berarti bahwa manajemen aset dan struktur modal berpengaruh signifikan terhadap profitabilitas pada PT Adhi Karya (Persero), Tbk yang terdaftar di Bursa Efek Indonesia secara simultan.

Berdasarkan uji parsial (uji t) diperoleh untuk manajemen aset mempunyai nilai $t_{\text {hitung }}$ sebesar 10,170 $>t_{\text {tabel }}$ sebesar 2,045 dengan nilai signifikansi sebesar $0,000<0,05$. Berdasarkan nilai tersebut dapat disimpulkan bahwa $\mathrm{H}_{0}$ ditolak, artinya manajemen aset berpengaruh signifikan terhadap profitabilitas pada PT Adhi Karya (Persero), Tbk yang terdaftar di Bursa Efek Indonesia secara parsial. Sedangkan struktur modal mempunyai nilai $t_{\text {hitung }}$ sebesar $4,411>t_{\text {tabel }}$ sebesar 2,045 dengan nilai signifikansi sebesar 0,000 $<0,05$. Berdasarkan nilai tersebut dapat disimpulkan bahwa $\mathrm{H}_{0}$ ditolak, artinya struktur modal berpengaruh signifikan terhadap profitabilitas pada PT Adhi Karya (Persero), Tbk yang terdaftar di Bursa Efek Indonesia secara parsial.

\section{KESIMPULAN DAN SARAN}

\section{Kesimpulan}

a. Nilai rata-rata manajemen aset yang dihitung dengan menggunakan total assets turnover ratio adalah sebesar 0,5481 . Untuk struktur modal yang dihitung dengan menggunakan debt to assets ratio memiliki nilai rata-rata yaitu sebesar 0,8495 . Sedangkan rata-rata profitabilitas yang dihitung dengan return on assets pada PT Adhi Karya (Persero), Tbk yang terdaftar di Bursa Efek Indonesia tahun 2008-2015 adalah sebesar 0,0121. 
b. Dari hasil pengujian regresi linier berganda diperoleh persamaan regresi $\hat{Y}=0,112+0,029 X_{1}-0,136 X_{2}$. Persamaan regresi tersebut dapat diartikan bahwa manajemen aset berpengaruh positif sedangkan struktur modal berpengaruh negatif terhadap profitabilitas.

c. Dari uji koefisien korelasi diperoleh hasil nilai koefisien korelasi sebesar 0,894 , artinya terdapat korelasi atau hubungan yang sangat kuat antara manajemen aset dan struktur modal dengan profitabilitas. Sementara untuk uji koefisien determinasi diperoleh hasil bahwa profitabilitas dapat dijelaskan oleh manajemen aset dan struktur modal yaitu sebesar $80 \%$ dan sisanya $20 \%$ dijelaskan oleh variabel lain yang tidak dijelaskan dalam penelitian ini, seperti profit margin dan operating assets turnover.

d. Dari hasil uji statistik $F$ diperoleh $F_{\text {hitung }}>$ $F_{\text {tabel }}$ atau 57,938 > 3,328 maka $\mathrm{H}_{0}$ ditolak dan untuk tingkat signifikansi adalah $0,000<$ 0,05 , maka keputusan yang diambil adalah manajemen aset dan struktur modal berpengaruh signifikan terhadap profitabilitas.

e. Dari hasil uji statistik t diperoleh hasil bahwa secara parsial untuk variabel manajemen aset : $t_{\text {hitung }}>t_{\text {tabel }}$ yaitu $10,170>2,045$ dan tingkat signifikansi $0,000<0,05$ yang berarti manajemen aset berpengaruh signifikan terhadap profitabilitas secara parsial. Sementara untuk variabel struktur modal diketahui bahwa $t_{\text {hitung }}>t_{\text {tabel }}$ yaitu $4,411>$ 2,045 dan tingkat signifikansi $0,000<0,05$ yang berarti bahwa struktur modal berpengaruh signifikan terhadap profitabilitas secara parsial.

\section{Saran}

a. Sebaiknya perusahaan tidak menambah terlalu banyak aset apabila aset tersebut tidak dapat mendukung peningkatan penjualan karena aset yang terlalu besar justru akan menimbulkan biaya yang semakin besar juga, seperti biaya penyusutan maupun biaya pemeliharaan.

b. Sebaiknya perusahaan tidak menambah terlalu banyak hutang karena hutang yang terlalu tinggi akan menyebabkan biaya bunga menjadi tinggi yang akan berdampak pada penurunan laba perusahaan.

c. Sebaiknya perusahaan memaksimalkan penggunaan total aset yang dimiliki perusahaan agar dapat menghasilkan penjualan yang lebih tinggi sehingga perputaran aset untuk menghasilkan penjualan semakin besar juga serta akan turut meningkatkan laba perusahaan.

\section{E. DAFTAR PUSTAKA}

Astuti, Dewi. 2004. Manajemen Keuangan Perusahaan. Jakarta: Penerbit Ghalia Indonesia.

Baridwan, Zaki. 2004. Intermediate Accounting. Edisi VIII. Yogyakarta : BPFE.

Brigham, Eugene F dan Joel F, Houston. 2010. Dasar-dasar Manajemen Keuangan: Essential of Financial Management, Edisi Kesebelas, Buku Satu. Jakarta: Salemba Empat.

Fraser, Lyn M. dan Aileen Ormiston. 2008. Memahami Laporan Keuangan. Edisi VII. Cetakan I. Jakarta : Indeks.

Horne, James C. Van dan John M. Wachowicz. 2012. Prinsip-prinsip Manajemen Keuangan, Edisi ketiga belas, Buku 1. Jakarta : salemba Empat.

Kasmir. 2010. Pengantar Manajemen Keuangan. Edisi Pertama, Cetakan Pertama. Jakarta: Kencana.

Martani, Dwi dkk. 2012. Akuntansi Keuangan Dan Manajemen Berbasis PSAK, Jakarta: Salemba Empat.

Silaban, Pasaman dan Rusliaman Siahaan. 2011. Manajemen Keuangan Teori dan Aplikasi. Edisi II. Medan : Fakultas Ekonomi Universitas HKBP Nommensen.

Sudana, I Made. 2011. Manajemen Keuangan Perusahaan Teori dan Praktik. Surabaya : Erlangga. 